\title{
SICKNESS ABSENCE AMONG FORESTRY WORKERS IN THE NORTH OF SCOTLAND, 1958
}

\author{
BY \\ DONALD MCGREGOR \\ Craigdhu, Bonar Bridge, Sutherland
}

(RECEIVED FOR PUBLICATION MARCH 29, 1960)

The sickness absence records of 1,115 forest workers in the highlands of Scotland during 1958 were examined. Only absences of four days or more were considered. Two hundred and seventy of the workers were established and were therefore entitled to retirement pensions. There was a high proportion of older men among the established workers; but the sickness record of these men was generally better than that of the unestablished workers except in respect of cardiovascular disease, rheumatism, and arthritis.

Among forest workers as a whole, accidents off duty accounted for more sickness absence than accidents on duty, a reversal of the finding in the male working population at large. The second most important cause of sickness absence was back troubles of all kinds. Among the male working population at large the second most important cause of absence was bronchitis, a disease which among forest workers comes 13th on the list.

A comparison was made between the sickness absence record of the highland forest workers and a group of telephone construction gang hands performing broadly comparable work (as regards health hazards) in the same area but whose members were drawn from more urban homes. In general fewer forest workers than telephone gang hands went sick in 1958 for all common ailments except cardiovascular disease, a finding perhaps related to the greater average age of forest workers. When this difference in age was allowed for it was found that the greatest difference between the two groups of sickness records was in bronchitis, cardiovascular disease, and peptic ulcer and gastritis, in that order, and was to the advantage of the forest workers. Next came the upper respiratory tract infections. The least difference was in accidents, septic conditions, and rheumatism and arthritis.

The forestry workers whose absence from work because of sickness is described in this paper, are those employed by the Forestry Commission's Scottish (North) Conservancy. They live and work in the most northerly part of the mainland and in the islands of Skye and Raasay (Fig. 1). The special interest that attaches to the health and physique of this group of men is that they are almost without exception permanent country dwellers; and it has been possible to throw into relief this account of a group of country people's sickness during the year by contrasting it with the sickness experienced by a similar sized group of men, engaged on an occupation resembling forestry in many of its features, but drawn from a more urban home environment.

The records examined relate to the calendar year 1958. The mid-year population is unobtainable, as the Forestry Commission's annual counting day is
September 30. However, 1,115, the figure for September 30, 1958, is not exceptional as compared with previous years (between 1955 and 1958 it varied between 1,098 and 1,146), and provides an adequate measure of the average labour force employed in the Commission's forests in this part of the country throughout the year. The Commission's forests provide a permanent source of work for those who seek it, but many men only require casual or short term employment which is often available at busy seasons. For the regular worker there is a scheme under which he may, subject to length of service and satisfactory health record (examination by a doctor is not necessary) become a permanent, established employee entitled to superannuation benefits. At September 30, 1958 the total labour force of 1,115 was made up of 845 unestablished and 270 established workers. 


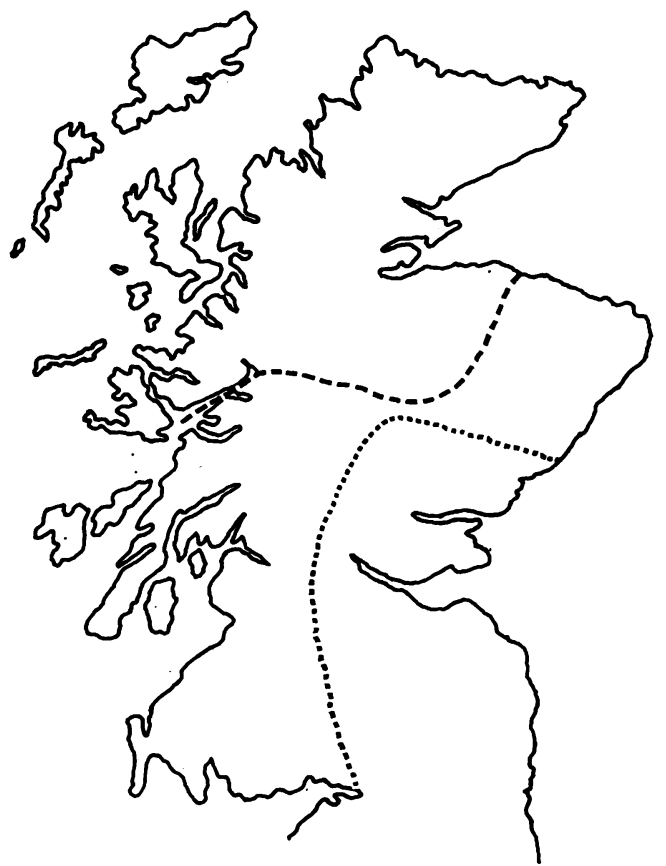

Fig. 1.-Map of Scotland showing areas worked by highland forest workers and telephone construction gangs; ........ southern boundary of North Scotland Conservancy of the Forestry Commission: ...... southern boundary of the area in which Aberdeen and West of Scotland telephone external construction gangs work.
Age Structure of the Labour Force

The dates of birth of a random sample, amounting to about $20 \%$ (227) of all the men who had been employed by the Commission in the area during 1958 , were noted and their ages worked out to the date September 30, 1958. Sixty-seven of the sample were established workers and 160 were unestablished. From the actual age structure of the sample an estimate was made of the age structure of the labour force at the counting date when the force amounted to 1,115 men. The results are given in Fig. 2 and Table 1 .

Two points call for comment. One is the concentration of older men among the established workers. This phenomenon is a constant and wellrecognized feature in the Commission's labour force in the North of Scotland. The other point is less expected. It is the surprisingly small representation of men aged 35 to 39 both among established and non-established groups. This finding may very well be a local manifestation of a countrywide phenomenon for agricultural and kindred occupations. Table 2 sets out some more or less comparable figures for the age structure of men occupied in agriculture, horticulture, and forestry as recorded in the 1951 Census for Scotland (General Registry Office, Edinburgh, 1956) and the highland forest workers described in this paper. The percentage age structure for highland forest workers found in 1958 has been converted into a hypothetical age structure for 1953 by moving the figures one

Fig. 2.-Estimated age structure of random sample of population at risk.

\section{Established}

Unestablished

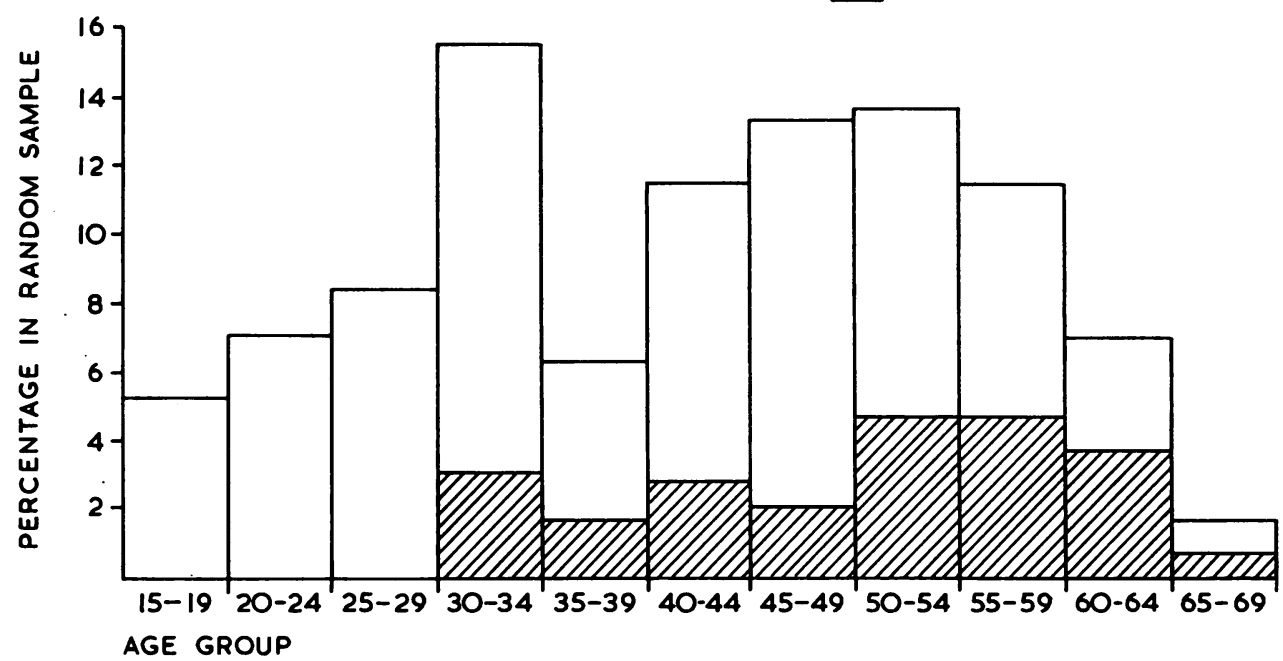


TABLE 1

ESTIMATED AGE STRUCTURE OF POPULATION AT RISK

\begin{tabular}{c|c|c|c}
\hline $\begin{array}{c}\text { Age Group } \\
\text { (years) }\end{array}$ & $\begin{array}{c}\text { Established } \\
\text { in } \\
\text { Labour Force } \\
\text { (estimated) }\end{array}$ & $\begin{array}{c}\text { Unestablished } \\
\text { in } \\
\text { Labour Force } \\
\text { (estimated) }\end{array}$ & $\begin{array}{c}\text { Age Structure } \\
\text { of } \\
\text { Labour Force } \\
\text { (estimated) }\end{array}$ \\
\hline $15-19$ & 0 & 58 & 58 \\
$20-24$ & 0 & 85 & 85 \\
$25-29$ & 0 & 101 & 101 \\
$30-34$ & 36 & 137 & 173 \\
$35-39$ & 16 & 53 & 69 \\
$40-44$ & 32 & 90 & 122 \\
$45-49$ & 24 & 126 & 150 \\
$50-54$ & 56 & 90 & 146 \\
$55-59$ & 56 & 63 & 119 \\
$60-64$ & 46 & 37 & 83 \\
$65-69$ & 4 & 5 & 9 \\
\hline Total & 270 & 845 & 1,115 \\
\hline
\end{tabular}

column to the left. In order to line these up with the census figures, the group in the latter for age 35-44 have been split in half, and so also for age 45-54. For the rest of the working life five-year groups are given in the Census Report. The curiously small representation of the 34-39 group is noticeable both in the Census figures and in those derived from the count of highland forest workers.

\section{Sickness and Accident Absence}

In this review no account has been taken of uncertificated or doubtfully certificated absences of one, two, or three days only; but in a few cases where absences of one, two, or three days were found with medical certificates bearing doctors' signatures, these have been counted. For various reasons these short absences are different in kind as well as in length from absences of four days or more. They are generally accompanied by a less precise medical diagnosis, if indeed they are accompanied by a medical certificate at all, and in practice it is sometimes difficult to distinguish them from
TABLE 2

AGE STRUCTURE OF NORTH SCOTTISH FOREST LABOUR FOR CE, AND THAT OF MEN FOLLOWING AGRICULTURAL OCCUPATIONS IN SCOTLAND AT THE TIME OF THE 1951 CENSUS

\begin{tabular}{|c|c|c|c|}
\hline Age Group & $\begin{array}{l}\text { N. Scottish } \\
\text { Foresters } \\
\text { (1958) }\end{array}$ & $\begin{array}{c}\text { N. Scottish } \\
\text { Foresters } \\
\text { (estimated } \\
\begin{array}{c}\text { 1953) } \\
\text { (953) }\end{array}\end{array}$ & $\begin{array}{c}\text { \% } \\
\text { Agricultural, } \\
\text { Horticultural } \\
\text { and } \\
\text { Foresters } \\
\text { (1951) }\end{array}$ \\
\hline $\begin{array}{l}15-19 \\
20-24 \\
25-29 \\
30-34 \\
35-39 \\
40-44 \\
45-49 \\
50-54 \\
55-59 \\
60-64 \\
65-69\end{array}$ & $\begin{array}{r}4.8 \\
7.0 \\
8.4 \\
15.4 \\
6.2 \\
11.0 \\
13.2 \\
13.7 \\
11.4 \\
7.0 \\
0.9\end{array}$ & $\begin{array}{r}7.0 \\
8.4 \\
15.4 \\
6.2 \\
11.0 \\
13.2 \\
13.7 \\
11.4 \\
7.0 \\
0.9 \\
-\end{array}$ & $\begin{array}{r}10.4 \\
9.9 \\
10.4 \\
8.7 \\
10.2 \\
10.2 \\
9.2 \\
9.2 \\
7.1 \\
6.2 \\
4.1\end{array}$ \\
\hline
\end{tabular}

absences attributable to some cause other than sickness. As this review concentrates on the kinds of sickness absence which accompany different diagnoses, no useful purpose is served by taking into account absences whose diagnostic attribution is questionable.

The diagnoses have been coded according to the 3-figure International Statistical Classification and then grouped under 32 convenient headings, whose brief title indicates the diagnoses which for the most part make up each group (Appendix I). The last of these headings, "Back troubles of all sorts" refers to a syndrome of particular importance among this group of workers. The spells of sickness absence due to back troubles appear also higher up in the Table in their appropriate place according to the diagnosis appearing on the medical certificate. The detailed breakdown of the syndrome appears in Table 3.

Some of these diseases or groups of diseases are more important in their industrial aspect than

TABLE 3

BACK TROUBLES OF ALL SORTS IN FOREST WORKERS OF NORTH SCOTTISH CONSERVANCY, 1958

\begin{tabular}{|c|c|c|c|c|c|}
\hline Diagnosis & $\begin{array}{c}\text { International } \\
\text { Statistical } \\
\text { Classification No. }\end{array}$ & $\begin{array}{c}1 \\
\text { No. of Workers } \\
\text { Affected }\end{array}$ & $\begin{array}{c}2 \\
\text { No. of Spells }\end{array}$ & $\begin{array}{c}\text { Total } \\
\text { Man Days } \\
\text { of Absence }\end{array}$ & $\begin{array}{c}3 \\
\text { Average } \\
\begin{array}{c}\text { Length of Spell } \\
\text { (days) }\end{array}\end{array}$ \\
\hline $\begin{array}{l}\text { Strained back } \\
\text { Inter-vertebral disc region }\end{array}$ & $\begin{array}{r}\text { N847 } \\
\text { N839 } \\
735\end{array}$ & $\begin{array}{r}14 \\
4\end{array}$ & $\begin{array}{r}14 \\
4\end{array}$ & $\begin{array}{l}227 \\
227\end{array}$ & $\begin{array}{l}16 \cdot 2 \\
56 \cdot 7\end{array}$ \\
\hline $\begin{array}{l}\text { Back injury } \\
\text { Lumbago } \\
\text { Sciatica } \\
\text { Backache } \\
\text { Sacroiliac strain } \\
\text { Other }\end{array}$ & $\begin{array}{r}\text { N996 } \\
726 \\
363 \\
787 \\
\text { N846 } \\
723\end{array}$ & $\begin{array}{r}4 \\
15 \\
6 \\
3 \\
4 \\
1\end{array}$ & $\begin{array}{r}4 \\
15 \\
6 \\
3 \\
4 \\
1\end{array}$ & $\begin{array}{r}106 \\
479 \\
240 \\
43 \\
97 \\
45\end{array}$ & $\begin{array}{l}26 \cdot 5 \\
31 \cdot 9 \\
40 \\
14 \cdot 3 \\
24 \cdot 2 \\
45\end{array}$ \\
\hline Total & - & 48 & 51 & 1,464 & $28 \cdot 7$ \\
\hline
\end{tabular}

1 Three workers had second attacks of back trouble with a different diagnosis.

2 Nine spells requiring reference to Treasury Medical Adviser.

3 Median spell 16 days. 
others. Appendix I gives certain facts about each. Column 1 gives the number of workers absent in the year, and the rate per 100 workers; column 2 the number of spells of absence in the year, and the rate per 100 workers; column 3 the number of mandays of absence, and the rate per 100 workers; column 4 the average length of spell; and column 5 the length of the median spell. After a forest worker has been absent for six weeks his case papers are referred to the Treasury Medical Adviser for an opinion on prognosis. Column 6 lists the number of cases so referred for each group of diagnoses. On average one out of every five spells of absence here recorded (121 out of 621) were referred in this way.

Column 3 (man-days of absence) records the feature about the absences which is, perhaps, of greatest economic importance to the industry, and Column 7 lists the figures in Column 3 in order of magnitude. This method of assessing the prevalence or importance of conditions in the various diagnostic groups provides a convenient measure for comparison between one industry and another. In Appendix $I$ it is remarkable that bronchitis is 13 th out of 32 listed causes as an overall source of sickness absence. It is hardly less notable that in this industry "accidents occurring off duty" come first and "back troubles" of all sorts second in man-days of absence per 100 employed.

Back Troubles.-Back troubles are a serious hazard of working life in many kinds of employment, but observations about them are still not collected in a form in which their natural history can be studied, or comparisons made of their rates of occurrence in different industries. In the International Statistical Classification they are dispersed under eight different codings, and in the groupings used by the Ministry of Pensions and National Insurance and by London Transport (1956) they are included with other syndromes in such a way that their prevalence cannot be determined. Yet the following "diagnoses", which occur commonly on medical certificates of absence, do not, in the opinion of the writer, necessarily represent different diseases or even always different symptoms, and are generally traumatic or auto-traumatic in origin: "strained back", "I.V.D." (inter-vertebral disc), "back injury", "lumbago", "sciatica", "backache", "sacro-iliac strain". As pointed out in the last section these back troubles are the second most common cause of sickness absence in forest workers, and the facts relating to their occurrence in the North Scottish Conservancy are detailed in Table 3.

In the syndrome of "back trouble" increasing age is an important factor (Table 4).
TABLE 4

DISTRIBUTION OF BACK TROUUBLES BY AGE IN FOREST WORKERS, 1958

\begin{tabular}{c|c|c|c}
\hline $\begin{array}{c}\text { Age Group } \\
\text { (years) }\end{array}$ & $\begin{array}{c}\text { Population } \\
\text { at Risk } \\
\text { (estimated) }\end{array}$ & $\begin{array}{c}\text { No. with } \\
\text { Back Troubles }\end{array}$ & $\begin{array}{c}\text { \% of } \\
\text { Population } \\
\text { at Risk with } \\
\text { Back Troubles }\end{array}$ \\
\hline $15-19$ & 58 & 0 & 0 \\
$20-24$ & 85 & 0 & 0 \\
$25-29$ & 101 & 4 & 4 \\
$30-34$ & 173 & 5 & $2 \cdot 9$ \\
$35-39$ & 69 & 3 & $4 \cdot 3$ \\
$40-44$ & 122 & 3 & $2 \cdot 5$ \\
$45-49$ & 150 & 7 & $4 \cdot 7$ \\
$50-54$ & 146 & 6 & $4 \cdot 1$ \\
$55-59$ & 119 & 9 & $7 \cdot 6$ \\
$60-64$ & 83 & 7 & $11 \cdot 1$ \\
$65-69$ & 9 & 1 & \\
\hline Total & 1,115 & $45 *$ & \\
\hline
\end{tabular}

* Age was not recorded for three workers.

Accidents.-Accidents occurring on duty in 1958 accounted for less lost time than accidents occurring off duty, a reversal of the situation in most years among the male working population as a whole. The difference was not large, however, and the total numbers of lost time accidents occurring in a single year were relatively small.

TABLE 5

ANALYSIS OF ACCIDENTS BY NATURE OF INJURY

\begin{tabular}{l|c|c}
\hline $\begin{array}{c}\text { Group and International } \\
\text { Statistical Classification No. }\end{array}$ & $\begin{array}{c}\text { No. of } \\
\text { Spells of Absence } \\
\text { due to On-duty } \\
\text { Accidents }\end{array}$ & $\begin{array}{c}\text { No. of } \\
\text { Spells of Absence } \\
\text { due to Off-duty } \\
\text { Accidents }\end{array}$ \\
\hline Burns N940-949 & 0 & 2 \\
Fractures N800-829 & 2 & 4 \\
Strains N839-848 & 15 & 29 \\
Open wounds N870-898 & 15 & 7 \\
Superficial injury N910-918 & 0 & 2 \\
Head injury N850-856 & 1 & 10 \\
Contusions N920-929 & 4 & 16 \\
Unspecified injuries N996 & 28 & 0 \\
Frostbite N980 & 1 & 71 \\
\hline Total & 66 & \\
\hline
\end{tabular}

Table 5 lists the nature of the injuries received in on-duty and off-duty accidents, and Table 6 the region of the body involved. As regards on-duty accidents, it is instructive to compare these Tables with a survey of all accidents, taking place on duty (whether absence is caused or not) in a sample of the Forestry Commission's forests drawn from all conservancies. Such a sample survey is made annually by the Commission. It does not, unfortunately, follow the codings of the International Statistical Classification; but it records that open wounds, strains and sprains, and contusions are the commonest injuries in that order. The lesser frequency of open wounds and the greater frequency of sprains and strains in off-duty accidents lends emphasis to this finding and indicates the special 
dangers associated with work which requires the use of axes, billhooks, etc. The Forestry Commission's survey also records the particular vulnerability of the upper and lower limbs in on-duty accidents. This is in contrast to the vulnerability of the back and the frequency of injuries to the head in off-duty accidents.

TABLE 6

ANALYSIS OF ACCIDENTS BY SITE OF INJURY

\begin{tabular}{l|c|c}
\hline \multicolumn{1}{c|}{ Site of Injury } & $\begin{array}{c}\text { No. of } \\
\text { Spells of Absence } \\
\text { due to On-duty } \\
\text { Accidents }\end{array}$ & $\begin{array}{c}\text { No. of } \\
\text { Spells of Absence } \\
\text { due to Off-duty } \\
\text { Accidents }\end{array}$ \\
\hline Head (1) & 1 & 9 \\
Shoulder & 3 & 4 \\
Arm & 1 & 1 \\
Hand and fingers & 16 & 10 \\
Back & 12 & 18 \\
Chest & 4 & 8 \\
Leg & 7 & 3 \\
Knee & 4 & 5 \\
Feet and toes & 13 & 12 \\
Site not stated & 5 & 4 \\
\hline Total & 66 & $74(2)$ \\
\hline
\end{tabular}

(1) Injury to the head or face.

(2) Multiple sites in some cases.

Established Workers.-As has been stated, an establishment system is in force which allows retirement pensions to selected workers. The process of selection aims at securing from the established worker a reasonably good record of sickness absence. Table 7 indicates the extent to which this was achieved in 1958 in the north of Scotland by comparing the percentage of established workers absent as a result of certain common ailments during the year with the corresponding percentage for the labour force as a whole. It will be seen that the record of the established workers

TABLE 7

ESTABLISHED WORKERS EXPERIENCING SICKNESS ABSENCE IN 1958, COMPARED WITH THE LABOUR FORCE AS A WHOLE

\begin{tabular}{|c|c|c|c|c|}
\hline & \multicolumn{2}{|c|}{$\begin{array}{l}\text { Established } \\
\text { Workers }\end{array}$} & \multicolumn{2}{|c|}{$\begin{array}{l}\text { Labour Force } \\
\text { as a Whole }\end{array}$} \\
\hline & No. & $\%$ & No. & $\%$ \\
\hline $\begin{array}{l}\text { No. employed at Sept. } 30,1959 \\
\text { Average age }\end{array}$ & $\begin{array}{l}270 \\
49 \text { yrs } \\
9 \text { mths }\end{array}$ & $100 \cdot 0$ & $\begin{array}{l}1,115 \\
34 \text { yrs } \\
9 \text { mths }\end{array}$ & $\begin{array}{c}100 \cdot 0 \\
-\end{array}$ \\
\hline $\begin{array}{l}\text { Men experiencing sickness ab- } \\
\text { sence } \\
\text { Two spells } \\
\text { Three spells } \\
\text { Four spells } \\
\text { Spells }>36 \text { days } \\
\text { Spells }>72 \text { days } \\
\text { No. absent due to }\end{array}$ & $\begin{array}{r}82 \\
12 \\
3 \\
1 \\
33 \\
16\end{array}$ & $\begin{array}{r}30.4 \\
4.5 \\
1 \cdot 1 \\
0.4 \\
12 \cdot 2 \\
5.9\end{array}$ & $\begin{array}{r}423 \\
67 \\
22 \\
4 \\
105 \\
42\end{array}$ & $\begin{array}{c}38 \\
6 \\
2 \\
0 \cdot 4 \\
9 \cdot 4 \\
3 \cdot 8\end{array}$ \\
\hline $\begin{array}{l}\text { Accidents on duty } \\
\text { Accidents off duty } \\
\text { Influenza } \\
\text { Back troubles } \\
\text { Septic conditions } \\
\text { Peptic ulcer and gastritis } \\
\text { Rheumatism and arthritis } \\
\text { Cardiovascular disease }\end{array}$ & $\begin{array}{r}4 \\
13 \\
17 \\
9 \\
4 \\
4 \\
9 \\
5\end{array}$ & $\begin{array}{l}1 \cdot 5 \\
4 \cdot 8 \\
6 \cdot 3 \\
3 \cdot 3 \\
1 \cdot 5 \\
1 \cdot 5 \\
3 \cdot 3 \\
1 \cdot 8\end{array}$ & $\begin{array}{l}62 \\
69 \\
74 \\
48 \\
24 \\
20 \\
34 \\
16\end{array}$ & $\begin{array}{l}5 \cdot 5 \\
6 \cdot 2 \\
6 \cdot 6 \\
4 \cdot 3 \\
2 \cdot 2 \\
1 \cdot 8 \\
3 \cdot 0 \\
1 \cdot 4\end{array}$ \\
\hline
\end{tabular}

was actually better than that of the whole labour force in most respects, in spite of their being consistently older. Thus fewer established workers experienced sickness absence, and fewer were absent as a result of accident and most forms of sickness. A slightly higher percentage than average of established men was absent on account of cardiovascular illness and rheumatism and arthritis, illnesses which are both more frequent as age advances, and a higher percentage than average was absent for long spells extending over more than six weeks.

\section{Sickness Absence of Forest Workers compared with that of Post Office Telephone External Construction Gangs}

The environmental factors that influence health are broadly divisible into those deriving from the place and nature of a man's work, and those deriving from the place and nature of his home. It would be instructive to compare the health record of two groups of highlanders, one doing forestry and one some different occupation. This has not been possible. It has, however, been possible to compare the health record of highland forest workers in 1958 with a similar sized group of men drawn from a distinctly less rural home environment doing similar work in the highland area during the same year.

The workers chosen for comparison are those who constitute the outdoor construction gangs of the Post Office telephone districts of Aberdeen and the west of Scotland. There are about 750 of these men compared with 1,115 forest workers. All these men operate in the highland area, the telephone men over a larger area than the forest workers (Fig. 1). In both occupations work is done in small, widely separated gangs supervised by a man of higher technical training, the telephone men in gangs of four or five, the foresters in gangs of variable size of about six to 20 . Both groups work in the open air exposed to the full rigours of the climate. The telephone men can take shelter if necessary in their vehicles, the foresters in movable or semipermanent tilts. In the daily tasks of both groups there is a large element of sheer labouring, making considerable muscular demands, either in digging with pick and shovel, or in the manhandling of timber or rocks or apparatus. But at the same time there is a craft element in which tool work becomes progressively more skilled under the influence of repetition and native talent and the example of fellow workers. Both groups have a packed lunch at midday. The working environment of both groups is therefore similar in exposure to the elements, in liability to severe muscular strain, in packed lunches, and in the freedom from the compulsions of mass activities. Finally both groups 
TABLE 8

LACERATIONS (N870-898) AMONG FOREST WORKERS AND POST OFFICE TELEPHONE CONSTRUCTION GANGS \begin{tabular}{l|c|c|c|c}
\hline & No. of Men & $\begin{array}{c}\text { No. of } \\
\text { On-duty } \\
\text { Accidents }\end{array}$ & $\begin{array}{c}\text { Lacerations } \\
\text { N870-898 }\end{array}$ & $\begin{array}{c}\text { Lacerations } \\
\text { as } \\
\text { percentage } \\
\text { of On-duty } \\
\text { Accidents }\end{array}$ \\
\hline $\begin{array}{l}\text { Forest workers } \\
\begin{array}{c}\text { P.O. construc- } \\
\text { tion gangs }\end{array}\end{array}$ & 1,115 & 62 & 15 & 25 \\
\hline
\end{tabular}

are equally insulated by space and fresh air from close contact with their workmates.

There is one important difference in the working environment. The forest worker is often occupied on tasks which require cutting tools, axe, slasher, bill, saw, and the like. The tools which the telephone engineer uses are less obviously dangerous. Thus open wounds (N870-898) figure more largely among the on-duty accidents of the forester $(25 \%)$ than among on-duty accidents of the post office telephone construction gang hand $(6 \%)$ (Table 8$)$.

The home environment of these two groups is very different. To express the difference quantitatively would require an elaborate social survey; but basically the difference is one of the degree of urbanization. The forest worker's home is frequently an isolated cottage or one of a pair of cottages a quarter of a mile or more from the next dwelling. Or it may be one of a group of a dozen or fewer cottages without community services such as constitutes a highland "township" or hamlet. Some forest workers live in small villages with a population of less than 1,000 .

The Post Office telephone ganger normally returns home each evening, but for long periods of up to three or four months and sometimes more in a year, he may be in lodgings away from home. These lodgings may be in the villages of 1,000 population or less, but the men's homes are in towns with populations of over 2,000 and up to 200,000 such as

TABLE 9

AGE STRUCTURE OF RANDOM SAMPLE OF FOREST WORKERS AND POST OFFICE TELEPHONE CONSTRUCTION GANGS

\begin{tabular}{c|c|c}
\hline \multirow{2}{*}{$\begin{array}{c}\text { Age Group } \\
\text { (years) }\end{array}$} & \multicolumn{2}{|c}{$\begin{array}{c}\text { Percentage of Men in each Age Group } \\
\text { of Random Sample }\end{array}$} \\
\cline { 2 - 3 } & Forest Workers & P.O. Telephone Gangs \\
\hline $15-19$ & $4 \cdot 8$ & $1 \cdot 4$ \\
$20-24$ & $7 \cdot 0$ & $8 \cdot 8$ \\
$25-29$ & $8 \cdot 4$ & $19 \cdot 0$ \\
$30-34$ & $15 \cdot 4$ & 22.6 \\
$35-39$ & $6 \cdot 2$ & $19 \cdot 4$ \\
$40-44$ & $11 \cdot 0$ & $7 \cdot 8$ \\
$45-49$ & $13 \cdot 8$ & $9 \cdot 2$ \\
$50-54$ & $13 \cdot 7$ & $7 \cdot 4$ \\
$55-59$ & $11 \cdot 4$ & $2 \cdot 3$ \\
$60-64$ & $7 \cdot 0$ & $2 \cdot 3$ \\
$65-69$ & 0.9 & 0 \\
\hline
\end{tabular}

6
Aberdeen, Inverness, Wick, Dingwall, Elgin, Oban, Fort William, or Tain.

Two further differences between the groups must be noted. One is that only about $25 \%$ of the forest workers are established (270 out of 1,115$)$, but about $92 \%$ (711 out of 776) of the Post Office gangs are on the establishment. In fact this constitutes less of a barrier to comparison than might be expected. There is also a considerable difference in age. The Post Office telephone gangers are much younger than the forest workers (Table 9 and Fig. 3), and to effect a fair comparison between their health records it has been necessary to allow for this.

Appendix II is a comprehensive table recording sickness absence of four days and over throughout 1958 for the commoner conditions. Columns 1-4 record the number and percentage of men absent in the whole of the two groups of workers under comparison. As noted above almost all the Post Office telephone gang hands are on the establishment, and for comparison columns 5 and 6 give the figures relating only to those of the forest workers who are established. It will be observed that both in the total number of spells of sickness absence experienced and in most of the common ailments, fewer of the foresters than of the Post Office gangers were concerned; this is true whether established men or the whole labour force is considered.

It is necessary to allow for differences in age between the two groups, and columns 7-10 show the numbers and percentage of those men under 50 in the two groups who experienced sickness absence. The better health record of the forest workers noticeable in the earlier columns is also visible here, and does not therefore depend to any great extent on the difference in age between the groups.

If it is granted that the working environment of the two groups is broadly similar in its health hazards, and that neither the difference in age nor the difference in numbers enjoying established status seem to have any notable effect on the differences in sickness absence, it is tempting to attribute the consistently better sickness record of the forest workers to some factor or factors in their home environment which may be conducive to better working health. The question of what these factors are is more easily asked than answered; but the information in columns 11 and 12 of Appendix II is at least suggestive.

Column 11 gives the ratio of the figures in column 10 to those in column 8 and expresses for the year under consideration the degree to which, for each ailment, the sickness absence record of the forest worker is better than that of the telephone gang hand. In column 12 these ratios are arranged in descending order of magnitude. 


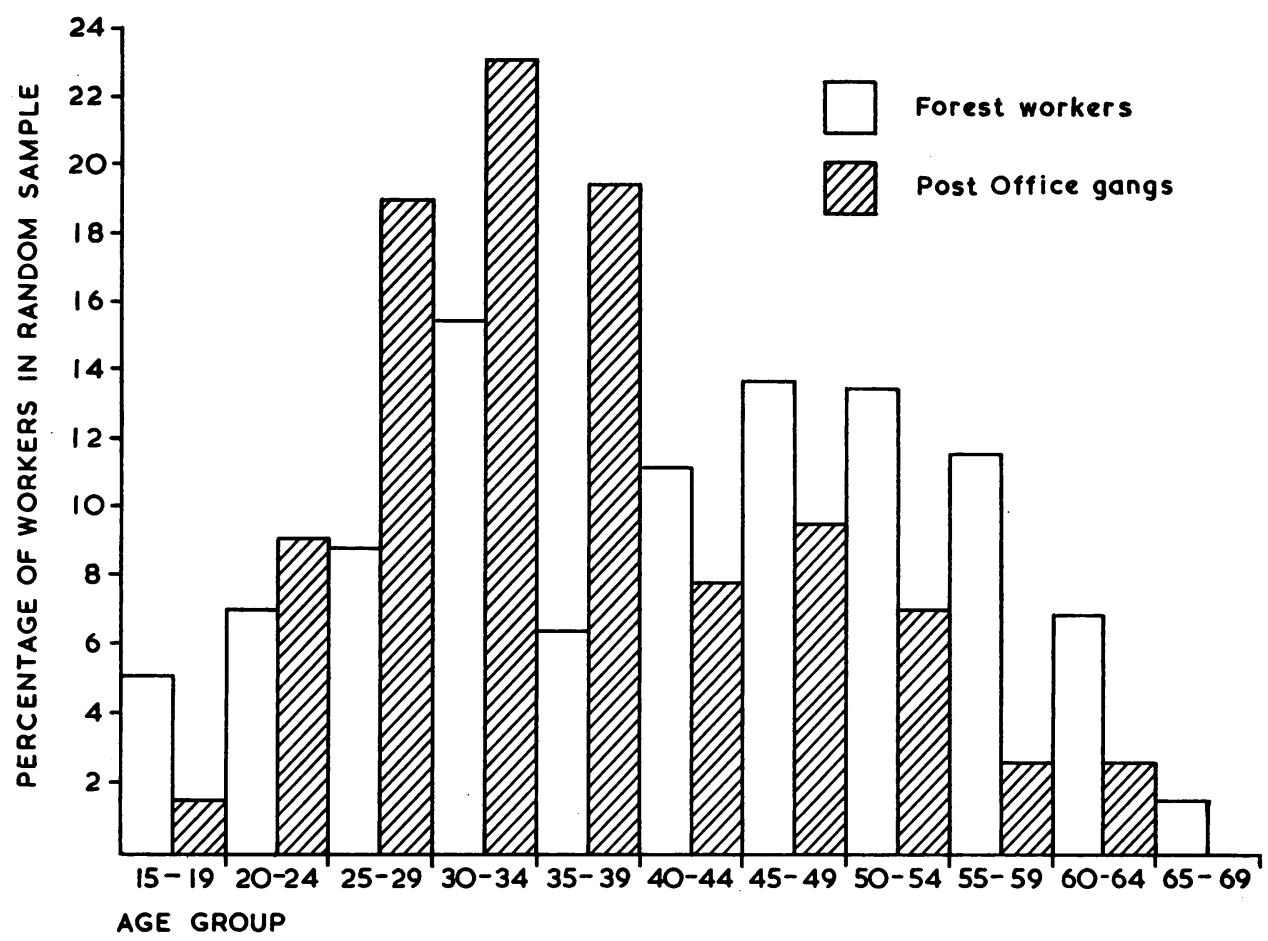

Fig. 3.-Age structure of random sample of forest workers and Post Office telephone construction gangs.

Thus in respect of bronchitis, cardiovascular disease, and peptic ulcer and gastritis in that order, the worker from the more urban home was at the greatest disadvantage. Next in order come the upper respiratory tract infections, in which the man from the more urbanized home, or perhaps it should be said the man who more frequently exchanges a more urban for a less urban environment, is at a disadvantage. Last comes a group containing accidents, septic conditions (the sequelae, perhaps, of accidents) and rheumatic and back troubles in which the difference between the sickness absence records of the two groups is least marked. It must be recognized, however, that the numbers are small.
A larger group of men might well produce very different ratios.

My thanks are due to the Conservator of the North Scottish Conservancy of the Forestry Commission for access to the records of sickness absence; to the Telephone Managers of the Aberdeen and West of Scotland Telephone districts for providing the information which relates to the external construction gangs; and to the Treasury Medical Adviser for securing the essential permissions.

\section{REFERENCES}

General Registry Office, Edinburgh (1956). Census 1951 Scotland, Vol. IV Occupations and Industries, p. xiv. Table F. H.M.S.O., Edinburgh.

London Transport (1956). Health in Industry: A Contribution to the Study of Sickness Absence. Butterworth, London. 
A P P E N D I X I

SUMMARY OF ABSENCE FROM SICKNESS AND ACCIDENTS AMONG NORTH SCOTLAND FORESTRY WORKERS, 1958*

\begin{tabular}{|c|c|c|c|c|c|c|c|c|c|c|c|}
\hline \multirow[t]{2}{*}{ Nature of Illness } & \multirow{2}{*}{$\begin{array}{l}\text { International } \\
\text { Statistical } \\
\text { Classification } \\
\text { No. }\end{array}$} & \multicolumn{2}{|c|}{$\begin{array}{l}1 \\
\text { Workers } \\
\text { Absent }\end{array}$} & \multicolumn{2}{|c|}{$\begin{array}{c}2 \\
\text { Spells } \\
\text { of Absence }\end{array}$} & \multicolumn{2}{|c|}{$\begin{array}{l}3 \\
\text { Man-days } \\
\text { of Absence }\end{array}$} & \multirow{2}{*}{$\begin{array}{c}4 \\
\text { Average } \\
\text { Length } \\
\text { of Spell } \\
+\end{array}$} & \multirow{2}{*}{$\begin{array}{c}5 \\
\substack{\text { Median } \\
\text { Spell } \\
\dagger}\end{array}$} & \multirow{2}{*}{$\begin{array}{c}6 \\
\text { Cases Requiring } \\
\text { Reference to } \\
\text { Treasury } \\
\text { Medical Adviser }\end{array}$} & \multirow{2}{*}{$\begin{array}{l}\text { Order of } \\
\text { Column } 3\end{array}$} \\
\hline & & No. & $\begin{array}{c}\text { Rate } \\
\text { per 100 }\end{array}$ & No. & $\begin{array}{c}\text { Rate } \\
\text { per } 100\end{array}$ & No. & \begin{tabular}{|c|} 
Rate \\
per 100
\end{tabular} & & & & \\
\hline $\begin{array}{l}\text { Miacellaneous infections } \\
\text { Benign neoplasms } \\
\text { Allergic disorders, etc. } \\
\text { Giandular, metabolic, and blood diseases } \\
\text { wychiatric illness } \\
\text { Bye disease } \\
\text { Car disease } \\
\text { Cardiac and vascular diseases } \\
\text { Common cold } \\
\text { Gore throat and tonsillitis } \\
\text { pluenza } \\
\text { Sinushitis }\end{array}$ & $\begin{array}{l}001-138 \\
210-239 \\
240-245 \\
250-299 \\
300-329 \\
370-389 \\
390-398 \\
352,400-468 \\
470 \\
472,473 \\
480-483 \\
590-502 \\
471,474,475\end{array}$ & $\begin{array}{r}4 \\
4 \\
8 \\
3 \\
4 \\
3 \\
3 \\
16 \\
17 \\
25 \\
74 \\
16\end{array}$ & $\begin{array}{c}3 \cdot 58 \\
3 \cdot 58 \\
7 \cdot 16 \\
2 \cdot 69 \\
3 \cdot 58 \\
2 \cdot 69 \\
2 \cdot 69 \\
14 \cdot 3 \\
15 \cdot 25 \\
22 \cdot 4 \\
66 \cdot 4 \\
14 \cdot 3\end{array}$ & $\begin{array}{r}4 \\
4 \\
10 \\
5 \\
5 \\
3 \\
3 \\
16 \\
18 \\
25 \\
79 \\
17\end{array}$ & \begin{tabular}{|l|}
$3 \cdot 58$ \\
$3 \cdot 58$ \\
$8 \cdot 96$ \\
$4 \cdot 48$ \\
$4 \cdot 48$ \\
$2 \cdot 69$ \\
$2 \cdot 69$ \\
$14 \cdot 3$ \\
$16 \cdot 1$ \\
$22 \cdot 4$ \\
$70 \cdot 8$ \\
$15 \cdot 25$
\end{tabular} & $\begin{array}{r}183 \\
243 \\
241 \\
586 \\
276 \\
39 \\
70 \\
674 \\
150 \\
279 \\
1,438 \\
494\end{array}$ & $\begin{array}{r}164.0 \\
218.0 \\
216.0 \\
526.0 \\
247.0 \\
34.9 \\
62.8 \\
603.0 \\
134.5 \\
250.0 \\
1,288 \\
443.0\end{array}$ & $\begin{array}{r}46 \\
61 \\
24 \\
117 \\
55 \\
13 \\
23 \\
42 \\
8 \\
11 \\
18 \\
29\end{array}$ & $\begin{array}{r}22 \\
16 \\
12 \\
54 \\
52 \\
16 \\
17 \\
23 \\
8 \\
9 \\
12 \\
22\end{array}$ & $\begin{array}{l}1 \\
1 \\
2 \\
4 \\
3 \\
1 \\
7 \\
- \\
5 \\
6\end{array}$ & $\begin{array}{l}\text { 26th } \\
20 \text { th } \\
21 \mathrm{st} \\
12 \text { th } \\
18 \text { th } \\
31 \mathrm{st} \\
\text { 30th } \\
\text { 9th } \\
27 \text { th } \\
\text { 17th } \\
\text { 3rd } \\
\text { 13th }\end{array}$ \\
\hline $\begin{array}{l}\text { Peptic ulcer and gastritis } \\
\text { Appendicitis } \\
\text { Gemia } \\
\text { Other digestive diseases }\end{array}$ & $\begin{array}{l}490,511-527 \\
540-545 \\
550-553 \\
560-561 \\
571 \\
530-539,572-\end{array}$ & $\begin{array}{r}22 \\
20 \\
3 \\
2 \\
14\end{array}$ & $\begin{array}{c}19 \cdot 7 \\
17 \cdot 9 \\
2 \cdot 69 \\
1 \cdot 79 \\
12 \cdot 55\end{array}$ & $\begin{array}{r}25 \\
21 \\
3 \\
2 \\
14\end{array}$ & $\begin{array}{l}22 \cdot 4 \\
18 \cdot 85 \\
2 \cdot 69 \\
1 \cdot 79 \\
12 \cdot 55\end{array}$ & $\begin{array}{l}598 \\
699 \\
133 \\
194 \\
344\end{array}$ & $\begin{array}{l}536 \cdot 0 \\
626 \cdot 0 \\
119 \cdot 2 \\
174 \cdot 0 \\
308 \cdot 5\end{array}$ & $\begin{array}{l}24 \\
33 \\
44 \\
97 \\
25\end{array}$ & $\begin{array}{l}15 \\
20 \\
45 \\
\frac{11}{11}\end{array}$ & $\begin{array}{l}4 \\
5 \\
3 \\
2 \\
4\end{array}$ & $\begin{array}{l}11 \text { th } \\
8 \text { th } \\
28 \text { th } \\
24 \text { th } \\
16 \text { th }\end{array}$ \\
\hline $\begin{array}{l}\text { Orchitis, hydrocoele, etc. } \\
\text { Septic conditions } \\
\text { Besema, dermatitis, etc. }\end{array}$ & $\begin{array}{l}594 \\
610-637 \\
690-698 \\
700-716 \\
720-727\end{array}$ & $\begin{array}{r}4 \\
5 \\
24 \\
5 \\
34\end{array}$ & $\begin{array}{c}3 \cdot 58 \\
4 \cdot 48 \\
21 \cdot 5 \\
4 \cdot 48 \\
30 \cdot 4\end{array}$ & $\begin{array}{c}4 \\
5 \\
25 \S \\
5 \\
36\end{array}$ & $\begin{array}{c}3 \cdot 58 \\
4 \cdot 48 \\
22 \cdot 4 \\
4 \cdot 48 \\
32 \cdot 3\end{array}$ & $\begin{array}{r}47 \\
273 \\
484 \\
115 \\
1,304\end{array}$ & $\begin{array}{r}42 \cdot 1 \\
245 \cdot 0 \\
434 \cdot 0 \\
103 \cdot 1 \\
1,170\end{array}$ & $\begin{array}{l}12 \\
55 \\
19 \\
23 \\
36\end{array}$ & $\begin{array}{l}\overline{30} \\
13 \\
13 \\
18\end{array}$ & $\begin{array}{l}\overline{2} \\
3 \\
\mathbf{1} \\
\mathbf{7}\end{array}$ & $\begin{array}{l}\text { 32nd } \\
\text { 19th } \\
\text { 14th } \\
\text { 29th } \\
\text { 5th }\end{array}$ \\
\hline $\begin{array}{l}\text { Chill and pyrexia of unknown origin } \\
\text { Neurodynia } \\
\text { Urinary and ssiatica } \\
\text { Urisease }\end{array}$ & $\begin{array}{l}730-749 \\
788 \\
783 \\
360-366 \\
600-605,786-\end{array}$ & $\begin{array}{r}18 \\
17 \\
3 \\
13\end{array}$ & $\begin{array}{r}16 \cdot 1 \\
15 \cdot 25 \\
2 \cdot 69 \\
11 \cdot 65\end{array}$ & $\begin{array}{r}18 \\
17 \\
3 \\
16\end{array}$ & $\begin{array}{l}16 \cdot 1 \\
15 \cdot 25 \\
2 \cdot 69 \\
14 \cdot 3\end{array}$ & $\begin{array}{l}602 \\
204 \\
194 \\
710\end{array}$ & $\begin{array}{l}540 \cdot 0 \\
183 \cdot 5 \\
174 \cdot 0 \\
636 \cdot 0\end{array}$ & $\begin{array}{l}33 \\
12 \\
65 \\
44\end{array}$ & $\begin{array}{r}16 \\
9 \\
74 \\
20\end{array}$ & $\frac{6}{2}$ & $\begin{array}{l}\text { 10th } \\
\text { 23rd } \\
24 \text { th } \\
7 \text { th }\end{array}$ \\
\hline $\begin{array}{l}\text { Miscellaneous other conditions } \\
\text { Accidents on duty } \\
\text { Accidents off duty } \\
\text { Untenown }\end{array}$ & $\begin{array}{l}789 \\
\text { N800-999 } \\
\text { N800-999 }\end{array}$ & $\begin{array}{r}5 \\
27 \\
62 \\
69 \\
16\end{array}$ & $\begin{array}{l}4 \cdot 48 \\
24 \cdot 2 \\
55 \cdot 6 \\
61 \cdot 9 \\
14 \cdot 3\end{array}$ & $\begin{array}{r}5 \\
30 \\
66 \\
71 \\
16\end{array}$ & $\begin{array}{l}4 \cdot 48 \\
26 \cdot 9 \\
59 \cdot 1 \\
63 \cdot 6 \\
14 \cdot 3\end{array}$ & $\begin{array}{r}239 \\
1,187 \\
1,347 \\
1,729 \\
399\end{array}$ & $\begin{array}{l}214 \cdot 5 \\
1,063 \\
1,205 \\
1,545 \\
357\end{array}$ & $\begin{array}{l}48 \\
40 \\
20 \\
24 \\
25\end{array}$ & $\begin{array}{r}34 \\
22 \\
14 \\
16 \\
8\end{array}$ & $\begin{array}{r}2 \\
11 \\
9 \\
13 \\
3\end{array}$ & $\begin{array}{l}\text { 22nd } \\
\text { 6th } \\
\text { 4th } \\
\text { 1st } \\
\text { 15th }\end{array}$ \\
\hline & N847, N996 & 48 & $43 \cdot 1$ & 51 & $45 \cdot 7$ & 1,464 & 1,313 & 29 & 16 & 9 & 2nd \\
\hline
\end{tabular}

Notes:

Excluding uncertificated absence of three days or under. $\S 15$ of these appear to have derived from external injury.

\section{A P P E N D I X I I}

COMPARISON OF THE SICKNESS ABSENCE EXPERIENCE OF POST OFFICE TELEPHONE EXTERNAL CONSTRUCTION GANGS AND NORTH OF SCOTLAND FOREST WORKERS, 1958

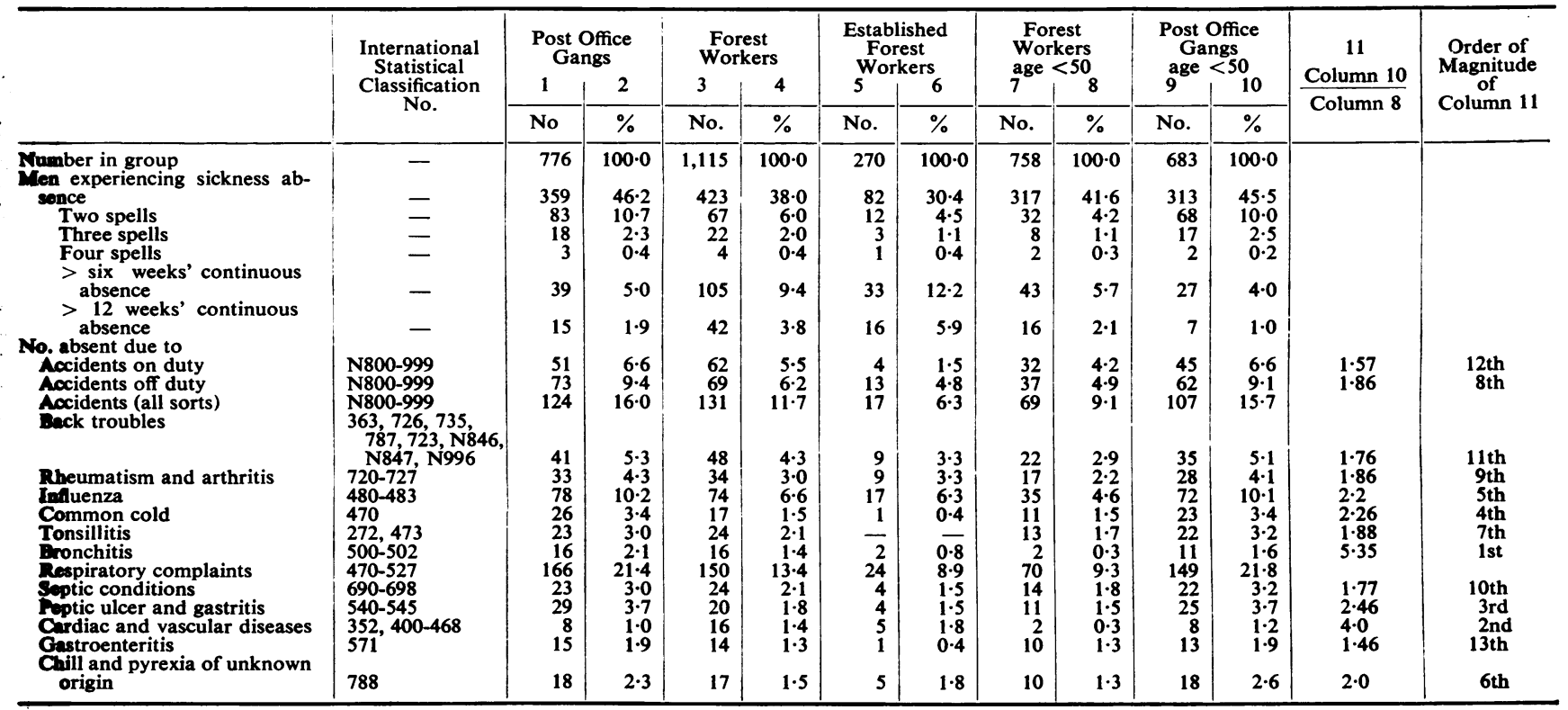

